\title{
Strategie rozwoju i modele biznesowe największych grup stoczniowych produkujących okręty w Unii Europejskiej
}

Jerzy Bieliński* iD

Tomasz Bieliński**

\section{Streszczenie}

Celem artykułu jest analiza strategii rozwoju i przyjętych modeli biznesowych w największych grupach kapitałowych zajmujących się budową i wyposażeniem okrętów w krajach Unii Europejskiej. Stwierdzono, że budowane okręty wojenne i ich wyposażenie stanowią największą część europejskiego przemysłu okrętowego. Przedmiotem oceny były brytyjska BAE Systems, francuska Naval Group, niemiecka TKMS, hiszpańska Navantia, SAAB Kockums w Szwecji, włoska Fincantieri oraz holenderski Damen.

$\mathrm{Z}$ analizy wynika, że jednym z podstawowych czynników kształtujących strategie rozwoju stoczni wojennych krajów UE jest polityka obronna i stworzone w ramach UE fundusze obronne. Zewnętrznymi czynnikami rozwoju jest także koniunktura na rynku statków wojennych. Czynniki te oraz przyjęte modele biznesowe znalazły swoje odzwierciedlenie w wielkości przychodów największych grup kapitałowych i marż zysku. Uzyskane dane wykazują na to, że kondycja finansowa tych firm nie jest stabilna. Modele biznesowe analizowanych

\footnotetext{
* Jerzy Bieliński, prof. dr hab., profesor emerytowany UG, Uniwersytet Gdański, Wydział Zarządzania, Katedra Ekonomiki Przedsiębiorstw, jerzy.bielinski@ug.edu.pl, https://orcid.org/00000002-9633-8457

** Tomasz Bieliński, dr, Uniwersytet Gdański, Wydział Ekonomiczny, Katedra Biznesu Międzynarodowego, tomasz.bielinski@ug.edu.pl, https://orcid.org/0000-0001-5290-3787
} 
przedsiębiorstw istotnie różnią się typami budowanych okrętów, strukturą własnościową i kapitałową. Wspólną cechą działania tych grup jest podejmowanie współpracy w realizacji projektów budowy okrętów w ramach UE oraz dążenie do konsolidowania tej produkcji w ramach dużych grup kapitałowych. Dynamika procesów konsolidacyjnych jest jednak stosunkowo niska i istnieje zagrożenie, że konkurencyjność stoczni wojennych może być niewystarczająca wobec agresywnych działań stoczni azjatyckich.

Słowa kluczowe: polityka bezpieczeństwa i obrony UE, budowa okrętów wojennych, okrętowe grupy kapitałowe stoczni wojennych, współpraca i konsolidacja stoczni, stocznie wojenne, przemysł zbrojeniowy.

\section{Wstęp}

Potrzeby ludzkie i sposoby ich zaspokajania kształtują rozwój każdej działalności człowieka. Realizowana jest ona w różnorodnych sektorach gospodarczych, kulturalnych i społecznych. Specyficznym sektorem działalności państwa jest obrona narodowa. Jej rozwój kształtuje ocena bezpieczeństwa narodowego, aktualne konflikty polityczne oraz ocena przyszłych potrzeb obronnych. Realizacja tych zadań i ocen odbywa się w przedsiębiorstwach produkujących odpowiednie rodzaje broni. $Z$ punktu widzenia państwa (a także obywatela) ważne jest to, aby potrzeby te były zaspokajane w sposób skuteczny i efektywny.

Środkiem do realizacji takiego celu jest opracowanie i wdrożenie określonej strategii rozwoju, która - w przypadku podmiotów gospodarczych - uzależniona jest od czynników zewnętrznych i wewnętrznych. Zewnętrznymi czynnikami wpływającymi na podmioty gospodarcze na poziomie makroekonomicznym są np. koniunktura ogólnogospodarcza, polityki państw, uwarunkowania społeczne i inne. Z kolei na poziomie sektora jest to przede wszystkim zmienność zapotrzebowania na jego produkty i usługi. Wewnętrzne uwarunkowania rozwoju podmiotów gospodarczych mają charakter produktowy, technologiczny i organizacyjny. Czynniki te mogą mieć charakter uniwersalny i występować we wszystkich sektorach lub charakter specyficzny - charakterystyczny tylko dla określonego sektora.

Jednym $\mathrm{z}$ takich sektorów jest będący przedmiotem artykułu sektor budowy okrętów wojennych. Okręt wojenny nie jest typowym produktem sprzedawanym na wolnym rynku. Konkurencyjność budowy okrętu związana jest przede wszystkim ze stopniem jego wyposażenia i skutecznością na polu walki. Zdecydowanie mniejszą rolę odgrywają tutaj koszty wykonywania tego produktu. Te dwie cechy istotnie wpływają na strategie rozwoju i warunki konkurencyjności w sektorze budowy okrętów. 
Celem artykułu jest analiza strategii rozwoju i przyjętych modeli biznesowych w przedsiębiorstwach produkujących okręty.

Podstawową metodą badawczą są studia przypadku. Do analizy wybrano największe europejskie grupy stoczniowe zajmujące się budową i wyposażaniem okrętów. W Europie największe grupy stoczniowe produkujące okręty znajdują się w Wielkiej Brytanii, we Francji, w Niemczech, Hiszpanii, Holandii oraz Rosji. Przeprowadzone zostały studia literaturowe dotyczące sektora okrętów wojennych oraz przeanalizowano dostępne dane ${ }^{1}$.

Doświadczenia badanych podmiotów gospodarczych oraz opracowania naukowe dotyczące stoczni wojennych mogą być pomocne w określaniu kierunków rozwoju tej części sektora przemysłu okrętowego w Polsce.

\section{Rola stoczni wojennych w realizacji celów obronnych krajów NATO i UE (wpływ NATO i UE na strategie stoczni wojennych)}

Największe grupy stoczniowe produkujące okręty wojenne są częścią systemu bezpieczeństwa i obrony krajów UE, w związku z czym w swojej strategii winny uwzględniać nadrzędne cele wyznaczane przez organy europejskie, takie jak Parlament Europejski czy Komisja Europejska. Ponieważ wszystkie kraje europejskie wchodzące w skład Unii Europejskiej są członkami NATO, realizują one cele polityki bezpieczeństwa i obrony określane przez rozwiązania i decyzje organów NATO. To sprawia, że zakres tej polityki ulega istotnemu rozszerzeniu geograficznemu. Staje się ona wspólnym działaniem krajów UE i transoceanicznych - wchodzących w skład NATO, ze szczególnym uwzględnieniem roli Stanów Zjednoczonych. USA dysponują bowiem nie tylko największą światową flotą wojenną, lecz również największymi zdolnościami produkcyjnymi stoczni wojennych i zakładami produkcji wyposażenia tych statków.

Kształtowanie podstawowych celów polityki bezpieczeństwa i polityki obronnej przez organy Unii Europejskiej i NATO stwarza istotny problem krajom europejskim w zakresie budowania własnej polityki. Kraje te z jednej strony czerpią korzyści wynikające z przynależności do tych ugrupowań, a z drugiej strony starają się zabezpieczyć interesy obronne własnych krajów.

Ugrupowania ponadnarodowe kształtują tylko takie cele nadrzędne, które nie ograniczają i nie wyznaczają celów szczegółowych dla poszczególnych krajów europejskich, ale mogą wspierać te działania, tworząc formy pomocy dla ich realizacji. Tego typu działania podejmuje Unia Europejska. Jednym z tych działań była

${ }^{1}$ Ze względu na brak danych w analizie pominięto rosyjską korporacje OSK (JSC United Shipbuilding Corporation). 
przyjęta przez Parlament Europejski w kwietniu 2016 r. rezolucja, w której wzywał on kraje Unii Europejskiej do zacieśnienia współpracy w zakresie badań nad obronnością, bazy przemysłowej i cyberobrony (European Parliament 2021, s. 2).

W tym samym roku przez Komisję Europejską został opracowany wniosek dotyczący rozporządzenia ustanawiającego europejski plan działań w sektorze obrony (European Defence Action Plan - EDAP). Celem tego programu jest wspieranie konkurencyjności i zdolności innowacyjnych UE, a jego elementem jest utworzenie Europejskiego Funduszu Obronnego. Fundusz ten składa się z dwóch odrębnych struktur finansowania („,okienek”), które wzajemnie się uzupełniają i których wprowadzanie rozstało rozłożone w czasie. Są to:

- „okno badawcze” umożliwiające finansowanie wspólnych projektów badawczych w dziedzinie obronności na poziomie UE;

- „okno zdolności” wspierające wspólny rozwój zdolności obronnych uzgodnionych przez państwa członkowskie.

„Okno badawcze” i „okno zdolności” różnią się pod względem charakteru prawnego i źródeł finansowania (European Commission 2016, s. 2). Deklaruje się, że w ramach okna badawczego UE będzie oferować bezpośrednie finansowanie (granty) na badania w zakresie innowacyjnych produktów i technologii obronnych - w całości finansowane z budżetu UE. Natomiast w ramach „okna zdolności" państwa członkowskie winny przeznaczać własne środki finansowe w celu wspólnego rozwijania zdolności obronnych, Unia Europejska zaś będzie współfinansowała te przedsięwzięcia z budżetu UE.

Europejski Fundusz Obronny został utworzony w 2017 r. Fundusz ten składa się z dwóch odrębnych części - jedna z nich przeznaczona jest na badania realizowane w latach 2017-2020, a druga przeznaczona jest na dofinansowanie działań poszczególnych krajów w zakresie rozwoju i przejęć w ramach specjalnego programu rozwoju obronnego i przemysłowego ze środkami finansowymi na lata 2019, 2020 i po roku 2020. Działania te zawarte zostały w planie Jeana-Claude'a Junckera.

Jednocześnie Parlament Europejski i Komisja Europejska wezwały państwa członkowskie do opracowania propozycji wzmocnienia europejskiej współpracy obronnej, w tym udoskonalenia powiązań między istniejącymi priorytetami w zakresie zdolności obronnych (European Parliament 2021, s. 2). Kraje europejskie, odpowiadając na rezolucje i propozycje Unii Europejskiej, a także posiadając określone doświadczenia historyczne, możliwości techniczne i gospodarcze oraz zasoby, wyznaczają przede wszystkim własne polityki w zakresie bezpieczeństwa i rozwoju.

Elementem polityki krajów europejskich jest strategia rozwoju produkcji okrętów wojennych. Choć możliwości produkcji okrętów wojennych w decydujący sposób warunkuje położenie geograficzne tych krajów, nie oznacza to jednak, że kraje bez dostępu do morza nie mogą się na tym polu realizować. W ich przypadku produkcja może polegać na wytwarzaniu elementów wyposażenia statków wojennych. 
Kraje europejskie, uwzględniając wyżej przywołane doświadczenia historyczne, możliwości techniczne i gospodarcze oraz posiadane zasoby, rozwijają w różnym zakresie wojenną produkcję okrętową. R. Bellais zwraca uwagę na to, że rozwiązania przyjęte przez Unię Europejską ,są idealnymi narzędziami do promowania ściślejszej współpracy między europejskimi stoczniami morskimi w zakresie przyszłych zdolności oraz, jak można się spodziewać, do konsolidacji tego sektora obrony na poziomie europejskim" (Bellais 2017, s. 10).

\section{Okręty wojenne jako produkty przemysłu okrętowego - cechy ich budowy}

Okręty wojenne to grupa różnych typów statków o odmiennym przeznaczeniu, różnorodnej konstrukcji i odmiennej wielkości. Te różnice i odmienności powodują, że w zależności od rodzaju okrętów stocznie mogą budować je przy użyciu „uniwersalnego" wyposażenia lub za pomocą specjalnych urządzeń.

Najbardziej ogólny podział okrętów wojennych dotyczy ich klasyfikacji na okręty wojenne nawodne i okręty podwodne. Okręty nawodne różnią się przede wszystkim wielkością, złożonością konstrukcji, stopniem wyposażenia i kosztem budowy. Do największych okrętów pod tym względem należą lotniskowce i helikopterowce, okręty desantowo-transportowe, mniejsze (ale o wyporności powyżej 5000 ton) niszczyciele i krążowniki oraz fregaty. Niezwykle liczna jest grupa okrętów o stosunkowo małym tonażu i różnym stopniu wyposażenia bojowego oraz statków pełniących funkcje pomocnicze. Są to m.in. patrolowce, trałowce, stawiacze min, amfibie $\mathrm{i}$ inne.

W przypadku okrętów podwodnych istotnym wyróżnikiem jest sprawa napędu. W tym przypadku możemy mówić o okrętach wykorzystujących napęd konwencjonalny (elektryczno-spalinowy) oraz napęd atomowy. Tylko niewielka grupa stoczni jest jednak w stanie budować okręty o napędzie atomowym.

Zmiany koniunktury na światowym rynku okrętowym powodują, że z punktu widzenia strategii działalności stoczni wojennych ważny jest nie tylko rodzaj budowanych okrętów, lecz także ocena, czy opłacalna jest budowa statków handlowych. Podjęcie takiej decyzji wymaga uwzględnienia różnic w budowie okrętów wojennych i statków handlowych. Najogólniej różnice pomiędzy tymi statkami określają autorzy raportu „Warship and Naval Vessels Market: Global Industry Trends". Stwierdzają oni, że generalną cechą odróżniającą okręty wojenne od handlowych jest to, że pierwsze z nich są znacznie szybsze, bezpieczniejsze i bardziej zwrotne. „W przeciwieństwie do statków handlowych, które przewożą ładunki, okręty wojenne są zaprojektowane do przewozu tylko broni, amunicji i podstawowych zapasów dla załogi” (Warship and Naval Vessels 2020). 
Według brytyjskich autorów okręty wojenne różnią się od statków handlowych wielkością i złożonością. Przeciętny statek handlowy jest około 3 razy większy niż przeciętny statek wojskowy, jednocześnie przeciętny statek handlowy jest prostszy (m.in. ze względu na brak systemu uzbrojenia) niż przeciętny okręt wojenny. Stwierdzają oni, że ,większość statków handlowych to zasadniczo bardzo duże stalowe kadłuby ze stosunkowo małymi silnikami i niewielką załogą, a ich zadania mają być wystarczające jedynie do przemieszczenia statku z portu do portu, ale nic więcej (wyjątkami są pasażerskie i różne małe statki, takie jak holowniki). Okręty wojenne są natomiast kompaktowe i wyposażone w złożone czujniki, broń oraz systemy komunikacji i dystrybucji energii. Ten zestaw systemów odzwierciedla różnorodność funkcji okrętu wojennego, w przeciwieństwie do pojedynczej funkcji (zazwyczaj transportowej) wielu statków handlowych" (Birkler i in. 2005, s. 30).

Na złożoność okrętów wojennych jako produktów zwraca także uwagę P.R. Kulkarni, pisząc, że wynika ona z bardzo dużej liczby komponentów, podsystemów i systemów, które muszą być fizycznie i funkcjonalnie zintegrowane w okrętach wojennych (Kulkarni 2015).

Konsekwencją złożoności jest wysoka cena jednostkowa okrętów, która wynosi od $50 \mathrm{mln}$ euro dla okrętów patrolowych aż do $1 \mathrm{mld}$ euro dla najbardziej kompleksowych okrętów (Study on Industrial and Technological Competences 2016, s. 4). Podana przez autorów tego opracowania graniczna cena 1 mld dolarów jest obecnie wielokrotnie przekraczana, czego przykładem może być kwota 8 mld dolarów za zamówionego przez francuską marynarkę wojenną lotniskowca (Naval Vessels Market 2020).

Przeznaczenie okrętów i wysoka cena mają swoje konsekwencje w sposobie ich kontraktowania. Klientem dla okrętów wojennych są przede wszystkim przedstawiciele rządów. W procesie kontraktowania tych okrętów uczestniczy $\mathrm{z}$ reguły duża liczba pracowników rządowych będących specjalistami różnych dyscyplin. Rządowe procedury biurokratyczne są bardziej czasochłonne niż procedury firm komercyjnych. Proces kontraktowania spowalniany jest przez konieczność tworzenia szczegółowych specyfikacji technicznych, dokładną analizę wspólnych kosztów oraz proces zatwierdzania przez rząd. W pracy dla rządu wymagana jest większa dokumentacja niż przy transakcjach handlowych (Birkler i in. 2005, s. 34).

Złożoność konstrukcji powoduje, że projektowanie okrętów wojennych zajmuje więcej czasu ze względu na dużą ilość sprzętu i skomplikowanych systemów. Autorzy brytyjscy zwracają uwagę na długi czas potrzebny do zaprojektowania okrętu wojennego. Według nich ,zaprojektowanie okrętu wojennego może zająć dwa lata lub dłużej, w porównaniu z sześcioma miesiącami w przypadku statku komercyjnego. Wstępne prace projektowe nad fregatą lub okrętem podwodnym mogą być dziesięciokrotnie dłuższe niż w przypadku tankowca" (Birkler i in. 2005, s. 35). 
Wymienione cechy okrętów wojennych i sposobu ich budowy oraz wyposażenia wpływają na wyższe potrzeby w zakresie kwalifikacji personelu zatrudnionego w stoczniach budujących te statki. Konieczne jest zatrudnienie inżynierów, którzy posiadają specjalistyczną wiedzę związaną z funkcjonowaniem systemów wykorzystywanych przez marynarkę wojenną. Zdobycie takiego teoretycznego oraz praktycznego zaplecza może trwać dłużej niż 5 lat (a nawet, w przypadku niektórych specjalizacji, 10 lat) (Study on Industrial and Technological Competences 2016, s. 5).

Budowa okrętów wojennych jest bardziej wymagająca pod względem wyposażenia niż budowa statków komercyjnych, co powoduje, że stocznie wojskowe zatrudniają większy odsetek firm zajmujących się wyposażaniem niż stocznie komercyjne. Projekty wojskowe wymagają zaangażowania większej liczby osób posiadających umiejętności związane z bronią, elektroniką i komunikacją oraz ze znajomością standardów wojskowych. W przypadku budowy statków handlowych tego typu prace zwykle wykonywane są przez pracowników zewnętrznych na podstawie umowy zlecenia (Birkler i in. 2005, s. 40).

\section{Rola produkcji okrętów wojennych i ich podstawowi producenci w przemyśle okrętowym krajów UE}

Rola przemysłu okrętów wojennych w krajach UE może być oceniana w dwóch płaszczyznach. Jedna wynika z tego, że są one elementem europejskiego przemysłu obronnego, druga - że stanowią składową produkcji przemysłu okrętowego w krajach UE rozumianego jako łączna produkcja statków handlowych, wojennych oraz produkcja elementów wyposażenia dla obu typów statków.

Znaczenie przemysłu okrętów wojennych w europejskiej produkcji obronnej określa jego udział w wartości przychodów tego przemysłu. W 2019 r. europejski morski przemysł wojenny wygenerował przychody w wysokości 26 mld euro, co stanowiło $23 \%$ całkowitych europejskich przychodów z sektora obronnego (The Aerospace and Defence Industries Association of Europe 2020).

Budowa okrętów wojennych jest także niezwykle istotnym elementem wartości produkcji przemysłu okrętowego Europy. Wobec braku systematycznych danych statystycznych dla stoczni wojennych problem ten rzadko jest omawiany w literaturze i opracowaniach dotyczących sektora okrętowego. Według incydentalnych danych podawanych przez SEA Europe produkcja okrętów wojennych w 2013 r. wyniosła 10,8 mld euro, co stanowiło blisko $12 \%$ całej europejskiej produkcji okrętowej. Jak wynika z danych zamieszczonych w Tabeli 1, wartość ta jest większa od produkcji statków handlowych, która w 2013 r. wyniosła 9,5 mld euro, co stanowiło 10,45\% produkcji okrętowej 
krajów europejskich. Do wartości produkcji wojennej trzeba także dodać 4,2 mld euro produkcji wyposażenia statków wojennych. Jest to wyposażenie specyficzne dla tego typu statków.

Tabela 1. Wielkość i struktura europejskiego przemysłu okrętowego w 2013 r.

\begin{tabular}{|l|c|c|}
\hline \multicolumn{1}{|c|}{ Rodzaj produkcji } & Mld euro & Udzial \% \\
\hline Budowa statków handlowych & 9,5 & 10,45 \\
\hline Budowa okrętów wojennych & 10,8 & 11,88 \\
\hline $\begin{array}{l}\text { Produkcja stoczni remontowych (w tym przebudowy i konstrukcje } \\
\text { morskie) }\end{array}$ & 3,2 & 3,52 \\
\hline Produkcja wyposażenia okrętowego & 60,0 & 66,0 \\
\hline Produkcja wyposażenia okrętów wojennych & 4,2 & 4,62 \\
\hline Budowa megajachtów & 3,2 & 3,53 \\
\hline Razem & 90,9 & 100 \\
\hline
\end{tabular}

Źródło: opracowano na podstawie SEA Europe, Supplying, Building \& Maintaining the Future, 2014 Edition, s. 4.

W Europie dominującymi krajami pod względem wojennej produkcji okrętowej są Wielka Brytania, Francja, Niemcy, Włochy, Hiszpania i Holandia. Największy potencjał do budowy okrętów wojennych mają Wielka Brytania i Francja. Kraje te produkują zarówno nawodne okręty wojenne, jak i nuklearne łodzie podwodne. Znaczący potencjał posiadają także Niemcy. Ze względu na fakt, że kraj ten ma średniej wielkości flotę wojenną, istotna część produkcji przeznaczana jest na eksport. Do europejskich krajów o znaczącej wojennej produkcji okrętowej należy zaliczyć także Włochy. W kraju tym buduje się zarówno nawodne okręty wojenne, jak i łodzie podwodne. Z kolei Holandia posiadająca duże tradycje produkcji okrętów wojennych buduje mniejsze okręty wojenne, które przeznaczone są przede wszystkim na potrzeby krajowe (Smit i in. 2001, s. 195). Do europejskich krajów o produkcji wojennej mniejszych rozmiarów należy zaliczyć kraje skandynawskie - Szwecję, Finlandię i Danię². Okręty wojenne budują także Belgia, Polska, Chorwacja, Grecja, Portugalia i Rumunia.

Analizując europejski sektor produkcji morskich okrętów wojennych, trzeba uwzględnić fakt, że działa on w konkurencyjnym otoczeniu światowych producentów tego typu okrętów.

Światowy przemysł statków wojennych rozwinięty jest w wielu krajach świata. Zdecydowanie dominującą jest produkcja okrętów wojennych w USA. Według Frost \& Sullivan Ameryka Północna jest największym rynkiem na świecie, a wydatki krajów z tego regionu świata stanowią ponad 30\% łącznej, globalnej

${ }^{2}$ Do europejskich producentów statków wojennych należy zaliczyć Turcję należącą do NATO oraz Rosję. Rosja rozwija swoją wojenną produkcję jako konkurencyjną do produkcji realizowanej w krajach NATO. 
sumy wydatków na budowę wojskowych jednostek pływających (Global Naval Shipbuilding Market 2017).

R. Bellais podaje, ze światowy rynek okrętów wojennych w 2015 r. osiągnął wartość 40 mld USD, z czego 12 mld to wartość produkcji USA (Bellais 2017, s. 5). Szacuje się, że wartość produkcji Chin i Rosji wynosi 3-4 mld USD, a produkcja Europy (bez Rosji) to ok. 10 mld. Charakterystycznym jest to, że rynek USA jest chroniony przed konkurencją, a stocznie budują prawie wyłącznie na potrzeby floty krajowej. Podobnie w przypadku Chin i Rosji, które budują okręty przede wszystkim na rynek krajowy i również chronione są przed konkurencją zagraniczną. Inaczej jest w przypadku Europy, gdzie producenci niemal połowę swej produkcji eksportują. Należy przyjąć, że pozostałe 10 mld USD światowego rynku okrętów wojennych to produkcja zlokalizowana w takich krajach, jak: Korea Południowa, Japonia, Indie, Brazylia i Australia (Kulkarni 2015, s. 7). Trzeba jednocześnie zauważyć, że istotnymi graczami na globalnym rynku okrętów wojennych są niemal wszystkie kraje z dostępem do morza, które mają własną produkcję statków wojennych lub są importerami tych statków. Do krajów tych należą: Kanada, Meksyk, Brazylia Argentyna, Arabia Saudyjska, Izrael, Egipt, RPA i wiele innych. Tak szeroki zakres potencjalnych nabywców zainteresowanych produkcją lub importem okrętów wojennych wynika z tego, że w budżetach na obronę tych państw zarezerwowane są na ten cel określone środki finansowe. Kraje te regularnie realizują wydatki na modernizację lub rozwój flot wojennych.

Interesujące dane o produkcji okrętowej w okresie 2009-2018 podaje Hervé Guillou, jeden z dyrektorów (Chief-Executive-Officer) Naval Group. W wywiadach z lutego i marca 2020 r. podał on (na podstawie szacunkowych danych zebranych przez IHS Markit i The Stockholm International Peace Research Institute), że we wspomnianym okresie główni producenci okrętów wojennych zbudowali 422 jednostki, z tego w Europie 12 różnych producentów zbudowało 80 okrętów wojennych ${ }^{3}$.

W tym samym okresie:

- dwóch chińskich producentów (połączone grupy CSSC i CSIC) zbudowało 136 okrętów wojennych;

- Lockheed Martin i General Dynamics w Stanach Zjednoczonych wyprodukowało 78 takich okrętów;

- rosyjska korporacja OSK (JSC United Shipbuilding Corporation), która skupia 40 stoczni, zbudowała 68 okrętów;

- Hyundai Heavy Industries i Daewoo (HHI i DSME) w Korei Południowej (które niedawno ogłosiły połączenie tych korporacji) wyprodukowały 40 okrętów;

- stocznie Japonii zbudowały 19 okrętów (Guillou 2020a).

${ }^{3}$ Liczba ta nie obejmuje małych statków wojennych, takich jak przybrzeżne statki patrolowe i przybrzeżne statki dostawcze (Mackenzie 2020). 
Powyższe dane należy traktować jako ilustrację aktywności kontraktowej stoczni lub grup kapitałowych w produkcji okrętów wojennych poszczególnych krajów w podanych dziesięciu latach. Nie informują one jednak o potencjale i wynikach produkcyjnych wymienionych krajów. Jak bowiem podano wyżej, krajem zdecydowanie dominującym w produkcji okrętów wojennych są Stany Zjednoczone, a produkcja Chin czy Rosji stanowi mniej niż połowę wartości produkcji USA. Podobnie, dotyczy to krajów europejskich, których produkcja wprawdzie istotnie ustępuje Stanom Zjednoczonym, ale jest zdecydowanie większa niż Chin czy Rosji.

Niezwykle istotnym elementem jest przeznaczenie budowanych okrętów. Są kraje, które budują je na własne potrzeby, ale w części przypadków istotną rolę odgrywa eksport. Do tej ostatniej grupy należą stocznie krajów UE. Z dostępnych danych wynika, że z 80 zbudowanych przez stocznie europejskie okrętów aż 49 przeznaczonych było na eksport $(61,25 \%)$. Wymienione koncerny chińskie przeznaczyły na eksport tylko 11 okrętów, czyli $8,1 \%$ ogólnej liczby wyprodukowanych jednostek, rosyjska grupa okrętowa wyeksportowała ich 14, czyli 20,59\%, koreańskie korporacje wyeksportowały 13 okrętów, czyli 32,5\%, stocznie japońskie wyprodukowały wszystkie okręty na rynek krajowy, natomiast dwie stocznie w Stanach Zjednoczonych wyeksportowały tylko sześć okrętów, co stanowiło 7,7\% ogólnej ich liczby (Mackenzie 2020). Dane te ilustrują aktywność eksportową wymienionych stoczni i grup kapitałowych i pośrednio na ich podstawie można wnioskować o wartości produkcji przeznaczonej na eksport.

\section{Największe europejskie grupy kapitałowe produkujące okręty wojenne i ich rozwój}

W Europie okręty wojenne produkowane są w dwóch grupach stoczni. Jedna to grupa skupiająca stocznie funkcjonujące $w$ ramach krajowych koncernów wojskowych, wyspecjalizowane w budowie okrętów wojennych. Z reguły realizują one zadania zlecane przez ministerstwa obrony narodowej lub ich odpowiedniki w poszczególnych krajach. Druga grupa przedsiębiorstw realizująca kontrakty wojskowe to stocznie, w których z reguły dominują budowy statków handlowych, ale istotną częścią ich produkcji są okręty wojenne. Ta druga grupa stoczni najczęściej ma także charakter grup kapitałowych o złożonej strukturze własnościowej. Na uwagę zasługuje fakt, że stocznie te z reguły współpracują z europejskim zrzeszeniem stoczni w ramach SEA Europe, raportując do tej organizacji swoje wyniki produkcji.

Do pierwszej grupy stoczni o największych wartościach produkcji zaliczymy przede wszystkim brytyjskie stocznie zintegrowane w ramach BAE Systems, we 
francuskiej Naval Group (dawniej DCNS), w TKMS w Niemczech, w hiszpańskiej Navanti oraz SAAB Kockums w Szwecji. Druga grupa stoczni to włoska Fincantieri, holenderski Damen, i francuska Chantiers de l'Atlantique. Według danych Study on Industrial and Technological Competences (2016, s. 5) grupy te w połowie 2015 r. posiadały aż $98 \%$ z ponad 75 mld euro łącznego portfela zamówień marynarki wojennej na okręty.

Każdy z wymienionych wyżej podmiotów ma swoją historię powstania, przekształceń organizacyjnych i własnościowych, infrastruktury produkcyjnej, rozwoju produkcji i odmiennych wyników działalności. Poniżej przedstawiamy ich krótką charakterystykę i podstawowe wyniki działalności.

BAE Systems (Wielka Brytania) to największa grupa kapitałowa przemysłu obronnego w Europie i jedna z największych na świecie. W ramach produkcji lub koprodukcji buduje się tutaj samoloty, pojazdy opancerzone i systemy obrony antybalistycznej. Podstawowymi produktami tej spółki są okręty wojenne. Produkowana jest tutaj pełna gama okrętów wojennych, takich jak atomowe okręty podwodne, fregaty, niszczyciele czy amfibie. Grupa posiada stocznie w Scotstoun i Govan w Glasgow oraz zakłady VT Shipbuilding w bazie marynarki wojennej w Portsmouth.

Tabela 2. BAE Systems - grupa kapitałowa o dominującej produkcji wojennej

\begin{tabular}{|l|c|c|c|c|c|c|c|c|c|}
\hline Wyszczególnienie & $\mathbf{2 0 1 9}$ & $\mathbf{2 0 1 8}$ & $\mathbf{2 0 1 7}$ & $\mathbf{2 0 1 6}$ & $\mathbf{2 0 1 5}$ & $\mathbf{2 0 1 4}$ & $\mathbf{2 0 1 3}$ & $\mathbf{2 0 1 2}$ & $\mathbf{2 0 1 1}$ \\
\hline $\begin{array}{l}\text { Przychody } \\
\text { w mld USD* }\end{array}$ & 3,750 & 3,403 & 3,826 & 3,419 & 3,594 & 3,306 & 3,279 & 3,319 & 2,459 \\
\hline Zatrudnienie* & 15520 & 14015 & 14549 & 11599 & 11590 & 11693 & 11503 & 9228 & 15520 \\
\hline $\begin{array}{l}\text { Marża zysku BAE } \\
\text { Systems Marine } \\
\text { w \% }\end{array}$ & 7,77 & 9,24 & 9,77 & 6,20 & 6,18 & 4,51 & $-2,32$ & $-6,80$ & $-4,36$ \\
\hline $\begin{array}{l}\text { Marża zysku BAE } \\
\text { System Surface } \\
\text { Ships w \% }\end{array}$ & 4,61 & $-3,81$ & $-0,36$ & 3,48 & 2,36 & 5,51 & 3,81 & 3,55 & 1,71 \\
\hline
\end{tabular}

* Wartości łączne dla przedsiębiorstw BAE Systems Marine i BAE Systems Surface Ships

Źródło: opracowanie własne na podstawie danych z Orbis, https://orbis.bvdinfo.com/ (dostęp: 24.12.2020).

Z danych przypadających na lata 2011-2019 wynika, że dwa podstawowe podmioty grupy kapitałowej BAE Systems miały rosnące przychody z działalności operacyjnej. Od 2012 do 2019 r. istotnie zwiększyło się w nich zatrudnienie. Wskaźniki marży zysku w poszczególnych latach dla obu spółek wahały się, ale w 2019 r. miały korzystne wartości dodatnie na stosunkowo wysokim poziomie.

W Wielkiej Brytanii budowa okrętów wojennych odbywa się także w ramach koncernu obronnego Babcock International Group działającego między innymi w sektorach morskim, lądowym, lotniczym i jądrowym. Budowane są 
tutaj lotniskowce, fregaty patrolowe wielozadaniowe, małe łodzie bojowe i jednostki ratownicze. Koncern posiada swoje oddziały w całej Wielkiej Brytanii, w Rosyth, Bristolu, Devonport i Crawley. Przychody tej grupy z produkcji okrętów wojennych wynosiły w 2013 r. 2,31 mld USD, a w 2018 r. 2,27 mld USD, co stanowiło ok. 40\% wartości przychodów całej grupy (Global Naval Shipbuilding Market 2017).

Naval Group to francuska grupa, która przyjęła taką nazwę w czerwcu $2018 \mathrm{r}$. (poprzednio, w latach 2007-2017, funkcjonowała pod nazwą DCNS - Direction des Constructions Navales). Podstawową działalnością grupy jest produkcja okrętów podwodnych i nawodnych. Ważnym jest to, że w grupie okrętów budowane są łodzie podwodne zarówno o napędzie konwencjonalnym, jak i jądrowym. Buduje się tutaj dużą gamę okrętów nawodnych, a wśród nich m.in.: korwety, fregaty obronne i interwencyjne, fregaty wielozadaniowe, statki dowodzenia i lotniskowce. Produkowana jest także broń dla okrętów podwodnych i nawodnych. Obok okrętów grupa zajmuje się produkcją w sektorze energetycznym, działając w następujących branżach: odnawialne źródła energii morskiej, cywilna energia jądrowa, budowa baz morskich i elektrowni. Grupa posiada swoje jednostki organizacyjne w 10 miejscach we Francji oraz w 18 innych krajach. Dane dotyczące wielkości przychodów i zatrudnienia tej grupy przedstawia Tabela 3.

Tabela 3. Naval Group - grupa kapitałowa o dominującej produkcji okrętów wojennych

\begin{tabular}{|l|c|c|c|c|c|c|c|c|c|}
\hline \multicolumn{1}{|c|}{ Rok } & $\mathbf{2 0 1 9}$ & $\mathbf{2 0 1 8}$ & $\mathbf{2 0 1 7}$ & $\mathbf{2 0 1 6}$ & $\mathbf{2 0 1 5}$ & $\mathbf{2 0 1 4}$ & $\mathbf{2 0 1 3}$ & $\mathbf{2 0 1 2}$ & $\mathbf{2 0 1 1}$ \\
\hline $\begin{array}{l}\text { Przychody op. } \\
\text { w mld USD }\end{array}$ & 4,170 & 4,131 & 4,435 & 3,364 & 3,309 & 3,722 & 4,631 & 3,870 & - \\
\hline Zatrudnienie & 12289 & 13612 & 12788 & 12694 & 12953 & 12873 & 13458 & 12994 & 12657 \\
\hline
\end{tabular}

Źródło: opracowanie własne na podstawie danych z Orbis, https:/orbis.bvdinfo.com/ (dostęp: 24.12.2020).

Przychody operacyjne tej grupy kapitałowej wahają się. W latach 2012-2019 wynosily od 3,87 mld USD w 2012 r. do 4,17 mld w roku 20194. Wyjątkiem był rok 2013, w którym osiągnęły one najwyższą wartość, czyli 4,63 mld USD. W tym roku w grupie tej pracowało najwięcej osób. W latach 2013-2019 liczba zatrudnionych miała niewielką malejącą tendencję.

TKMS (Thyssen Krupp Marine Systems) to niemiecka grupa kapitałowa, która w swej historii nawiązuje do 175 letniej tradycji doświadczeń w budowie statków. Posiada swoje zakłady w Kilonii, Hamburgu, Bremie i Emden. TKMS ma cztery oddziały produkcyjne, które zajmują się budową okrętów podwodnych, budową okrętów nawodnych, takich jak m.in. fregaty i korwety, wytwarzaniem morskich systemów elektronicznych oraz wykonywaniem usług. TKMS jest także

${ }^{4} \mathrm{Na}$ swojej stronie internetowej grupa podaje, że w 2019 r. jej przychody wynosiły 3,7 mld euro, przy zatrudnieniu 15000 osób (Naval Group 2020). 
właścicielem 25\% akcji stoczni Hellenic Shipyards Co. w Skaramandzie w Grecji oraz posiada oddział w Karaczi w Pakistanie.

TKMS nie publikuje swoich danych dotyczących przychodów operacyjnych i wielkości zatrudnienia. Dysponujemy tylko incydentalnymi danymi dla niektórych lat. Według raportu Frost \& Sullivan TKMS w 2013 r. miało przychody o wartości 1,53 mld USD (Global Naval Shipbuilding Market 2017). Z kolei w 2015 r. według R. Bellais (2017) wartość produkcji TKMS wynosiła 1,70 mld euro, a grupa zatrudniała 3000 pracowników.

$\mathrm{Na}$ uwagę zasługuje fakt, że w Niemczech produkcją statków wojennych zajmują się także German Naval Yards Kiel (GNYK) i Fr. Lürssen Werft (przedsiębiorstwa te także nie publikują danych finansowych).

Navantia SA (dawniej Bazán lub IZAR) to hiszpańska grupa kapitałowa. Navantia SA po licznych przekształceniach, jakie przechodził hiszpański przemysł okrętowy, jest obecnie przedsiębiorstwem państwowym ze 100\% udziałem kapitałowym państwa (Navantia 2020). W jej skład wchodzą trzy stocznie: Ferrol Estuary Shipyard, Cartagena Shipyard oraz Bay of Cadic Shipyard. Stocznie te budują różnego typu okręty wojenne oraz statki cywilne. Okręty te przeznaczone są przede wszystkim dla Marynarki Wojennej Hiszpanii, a także na eksport, w tym np. dla Arabii Saudyjskiej. Navantia jest właścicielem 100\% akcji grupy Navantia w Australii. Firma buduje okręty na potrzeby marynarki wojennej Australii.

Tabela 4. Navantia SA - grupa kapitałowa o dominującej produkcji okrętów wojennych

\begin{tabular}{|l|c|c|c|c|c|c|c|c|c|}
\hline \multicolumn{1}{|c|}{ Rok } & $\mathbf{2 0 1 9}$ & $\mathbf{2 0 1 8}$ & $\mathbf{2 0 1 7}$ & $\mathbf{2 0 1 6}$ & $\mathbf{2 0 1 5}$ & $\mathbf{2 0 1 4}$ & $\mathbf{2 0 1 3}$ & $\mathbf{2 0 1 2}$ & $\mathbf{2 0 1 1}$ \\
\hline $\begin{array}{l}\text { Przychody op. } \\
\text { w mld USD }\end{array}$ & 1,386 & 1,250 & 1,041 & 0,766 & 0,765 & 0,681 & 0,986 & 1,213 & 1,641 \\
\hline Zatrudnienie & 4204 & 5066 & 5238 & 5323 & 5378 & 5455 & 5500 & 5537 & 5532 \\
\hline Marża zysku w \% & $-14,29$ & $-30,74$ & $-44,97$ & $-41,84$ & $-32,27$ & $-5,52$ & $-10,55$ & $-12,19$ & $-4,81$ \\
\hline
\end{tabular}

Źródło: opracowanie własne na podstawie danych z Orbis, https://orbis.bvdinfo.com/ (dostęp: 24.12.2020).

Podobnie jak w wyżej omówionych przykładach, przychody operacyjne tej grupy kapitałowej wahają się. W tym przypadku najniższe przypadają na $2014 \mathrm{r}$. i wynoszą 0,68 mld USD. Od tego roku mają jednak stałą tendencje rosnącą i w 2019 r. grupa osiągnęła przychody o wartości 1,39 mld USD. W stoczniach tej grupy systematycznie maleje zatrudnienie z 5,5 tys. w 2011 r. do 4,2 tys. w 2019 r. Zaskakująco niskie są wartości marży zysku tej grupy, które w całym okresie mają wartości ujemne. Skrajnie niskie, bo wynoszące prawie -45\%, są w 2017 r. W 2019 poprawiły się, ale w dalszym ciągu mają wartości ujemne (Tabela 4).

Istotnie mniejszą od wyżej przedstawionych grupą kapitałową produkującą okręty wojenne jest szwedzka SAAB. W jej skład wchodzą dwie historyczne stocznie w Karlskronie i Malmö. W 1990 r. te dwie stocznie połączyły się 
i przyjęły nazwę Kockums AB. W drugiej połowie XX w. Kockums było spółką państwową, która w wyniku kryzysu została sprzedana niemieckiej stoczni Howaldtswerke-Deutsche Werft. W 2005 r. przedsiębiorstwo to zostało wykupione przez niemiecki konglomerat przemysłowy Thyseen Krupp. Kierunki działalności realizowane przez niemieckich właścicieli spotkały się z krytyką władz szwedzkich. Zdaniem tych władz działania koncernu nie uwzględniały potrzeb szwedzkiego sektora wojennego, a niektóre traktowano wręcz jako eliminowanie konkurentów. W 2014 r. na podstawie porozumienia spółkę przejął szwedzki koncern obronny i ubezpieczeniowy SAAB. Grupa wyspecjalizowała się w budowie okrętów podwodnych i lekkich nawodnych okrętów uderzeniowych oraz korwet.

Tabela 5. SAAB Kockums AB - grupa stoczniowa o dominującej produkcji wojennej

\begin{tabular}{|l|r|r|r|r|r|r|r|r|l|}
\hline \multicolumn{1}{|c|}{ Rok } & $\mathbf{2 0 1 9}$ & $\mathbf{2 0 1 8}$ & $\mathbf{2 0 1 7}$ & $\mathbf{2 0 1 6}$ & $\mathbf{2 0 1 5}$ & $\mathbf{2 0 1 4}$ & $\mathbf{2 0 1 3}$ & $\mathbf{2 0 1 2}$ & $\mathbf{2 0 1 1}$ \\
\hline Przychody op. w mld USD & 0,293 & 0,337 & 0,341 & 0,257 & 0,220 & 0,211 & 0,261 & 0,286 & 0,216 \\
\hline Zatrudnienie & 1157 & 1128 & 1043 & 853 & 874 & 908 & 941 & 949 & 909 \\
\hline Marża zysku w \% & 1,57 & 5,93 & 5,13 & 5,39 & 10,38 & $-7,86$ & 2,15 & 1,63 & $-7,49$ \\
\hline
\end{tabular}

Źródło: opracowanie własne na podstawie danych z Orbis, https://orbis.bvdinfo.com/ (dostęp: 24.12.2020).

Przychody operacyjne tej grupy są istotnie mniejsze od wyżej wymienionych i wahają się od 0,216 w 2011 do 0,293 w 2019 r. Grupa zatrudnia średnio w całym okresie około tysiąca osób. Stocznia od roku 2015 osiąga dodatnie wskaźniki marży, chociaż w 2019 r. ma ona najniższą wartość (Tabela 5).

Produkcja wojenna, jak wspomniano wyżej, podejmowana jest także przez stocznie, w których dominuje budowa statków handlowych. Taką strategię realizuje największa europejska stoczniowa grupa kapitałowa, jaką jest włoska Fincantieri. Znana jest ona głównie z produkcji wycieczkowców i promów. Istotną częścią portfela zamówień tego przedsiębiorstwa są okręty wojenne. Fincanieri podaje (Fincanieri Naval Vessels 2016, s. 6), że produkuje okręty wojenne już 230 lat i w tym okresie zbudowano ich 2000 . Buduje się tutaj lotniskowce, niszczyciele, fregaty, korwety, okręty patrolowe, a także okręty pomocnicze i specjalne oraz okręty podwodne. Okręty te buduje się na zamówienia marynarki wojennej Włoch, a także innych krajów w ramach programów międzynarodowych. Zamówienia realizowane są we włoskich stoczniach tego koncernu oraz w spółkach zależnych w Stanach Zjednoczonych (kontrakty realizowane dla United States Navy). Okręty wojenne budowane są w dwóch stoczniach we Włoszech i trzech w USA. We Włoszech działają stocznie Muggiano i Riva Trigoso. Stocznia Muggiano zajmuje się budową okrętów podwodnych oraz małych specjalistycznych jednostek pływających, a także wyposażaniem jednostek nawodnych oraz usługami posprzedażnymi. Natomiast stocznia Riva Trigoso skupia się na budowie średnich i dużych okrętów nawodnych (Fincanieri Naval Vessels 2016, s. 6). 
Tabela 6. Fincantieri S.p.A. stocznia o dominującej produkcji statków handlowych budująca także okręty wojenne

\begin{tabular}{|l|c|c|c|c|c|c|c|c|c|}
\hline \multicolumn{1}{|c|}{ Rok } & $\mathbf{2 0 1 9}$ & $\mathbf{2 0 1 8}$ & $\mathbf{2 0 1 7}$ & $\mathbf{2 0 1 6}$ & $\mathbf{2 0 1 5}$ & $\mathbf{2 0 1 4}$ & $\mathbf{2 0 1 3}$ & $\mathbf{2 0 1 2}$ & $\mathbf{2 0 1 1}$ \\
\hline $\begin{array}{l}\text { Przychody op. } \\
\text { w mld USD }\end{array}$ & 6,623 & 6,268 & 6,021 & 4,674 & 4,558 & 5,340 & 5,256 & 3,149 & 3,080 \\
\hline Zatrudnienie & 19823 & 19274 & 19545 & 19181 & 20019 & 21689 & 20389 & 10240 & 9994 \\
\hline Marża zysku w \% & $-1,29$ & 2,24 & 1,68 & 0,50 & $-7,76$ & 2,14 & 1,99 & 1,48 & 1,04 \\
\hline
\end{tabular}

Źródło: opracowanie własne na podstawie danych z Orbis, https://orbis.bvdinfo.com/ (dostęp: 24.12.2020).

Z punktu widzenia wielkości przychodów można ocenić sytuację Fincantieri jako bardzo korzystną. W ocenianym okresie jej przychody operacyjne podwoiły się. Podobnie zwiększyło się zatrudnienie. Na stosunkowo niskim poziomie kształtuje się marża zysku, a w 2019 r. ma nawet wartości ujemne. Niestety wielkości te nie informują o udziale produkcji okrętów wojennych. Mieszczą się one w ogólnych wielkościach obejmujących statki handlowe. Natomiast autorzy raportu Raport Frost \& Sullivan podają, że produkcja wojenna tej grupy wynosiła w 2013 r. 1,550 mld USD a w 2018 r. 1,431 mld USD (Global Naval Shipbuilding Market 2017). Można więc przyjąć, że produkcja wojenna w tej grupie wynosi średnio ok. jednej czwartej wartości przychodów.

Kolejnym producentem okrętów w Europie jest Chantiers de l'Atlantique z Francji. Stocznia ta, podobnie jak Fincantieri, specjalizuje się w budowie statków pasażerskich, ale w strukturze produkcji znaczącą część stanowią okręty wojenne (buduje się tutaj także konstrukcje farm morskich). Stocznia ta przechodziła istotne zmiany właścicielskie, a także zmiany nazwy. Po kolejnych przekształceniach w 2017 r. włoska państwowa stocznia Fincantieri przejęła 50\% udziałów w STX France ${ }^{5}$, pozostawiając połowę w posiadaniu francuskiej Naval Grup i francuskiego rządu. Nastąpił także powrót stoczni Saint-Nazaire do jej pierwotnej nazwy Chantiers de l'Atlantique. Przychody operacyjne tej grupy w $2018 \mathrm{r}$. wynosily 1,81 mld USD a w 2019 r. 2,13 mld USD (Orbis 2020). Niestety brak jest danych odnośnie udziału produkcji wojennej w przychodach tej stoczni.

Do średnich producentów okrętów wojennych w Europie można także zaliczyć grupę okrętową Damen Shipyard B.V. Grupa ta w 2018 r. osiągnęła przychody operacyjne w wysokości 1,0 mld USD a w 2019 r. 1,21 mld USD (Orbis 2020), ale okręty wojenne stanowią mniejszą część ogólnej produkcji tej stoczni, w której dominują statki handlowe.

Z podstawowych danych dotyczących rozwoju grup kapitałowych o dominującej produkcji wojennej wynika, że dwie największe grupy, jakimi są BAE Systems oraz Naval Grup, istotnie zwiększyły swoje przychody operacyjne. SAAB

${ }_{5}^{5}$ STX France - była spółka południowo koreańskiego holdingu stoczniowego STX Offshore \& Shipbuilding. 
Kockums wykazywała stabilne wielkości przychodów. Wyraźnie niestabilny jest rozwój hiszpańskiej grupy Navantia SA. Choć w ostatnich latach przychody tej grupy wykazują tendencję rosnącą, to osiąga ona zdecydowanie niekorzystne wskaźniki marży zysku.

Uzyskane wielkości przychodów operacyjnych i marże zysku są wynikami realizowanych przez grupy kapitałowe strategii rozwoju oraz przyjętych modeli biznesowych.

\section{Strategie produktowe, własnościowe i kapitałowe stoczni budujących okręty wojenne w krajach UE}

Strategie rozwoju stoczni budujących okręty kształtowane są przez uwarunkowania zewnętrzne (w tym politykę NATO i polityki państwowe) i uwarunkowania wewnętrzne tych podmiotów gospodarczych. Uwarunkowania te stają się podstawą do wyboru określonego modelu biznesowego.

Modele biznesowe największych stoczni wojennych krajów UE uzależnione są od:

- typów i wielkości budowanych okrętów wojennych;

- przeznaczenia produkcji (tylko na potrzeby własnego kraju lub na eksport);

- prowadzenia działalności biznesowej samodzielnie lub w grupach kapitałowych;

- struktury własności (stocznie prywatne lub państwowe);

- ograniczenia się tylko do produkcji wojskowej lub łączenia produkcji okrętów i statków handlowych.

Model biznesowy stoczni wojennych związany jest przede wszystkim z typem budowanych okrętów. Kluczowe jest to, czy stocznie specjalizują się w budowie największych okrętów wojennych, czy też produkują inne mniejsze ich typy. Oczywiście wybór ten uzależniony jest od posiadanych zasobów. Największe okręty, jakimi są lotniskowce, a także duże krążowniki i niszczyciele, budują BAE Systems, Naval Group, Navantia i Fincantieri. Charakterystycznym jest, że stocznie te budują także szeroką gamę okrętów wojennych średniej wielkości, a nawet mniejsze statki pomocnicze.

Specyficznym typem okrętów wojennych są łodzie podwodne. Okręty te buduje szereg stoczni. Do najbardziej złożonych okrętów podwodnych należą te, które posiadają napęd atomowy. Tylko nieliczne stocznie są w stanie budować tego typu okręty - wśród nich są brytyjska BAE Systems oraz francuska Naval Group. Okręty podwodne o napędzie konwencjonalnym buduje szereg europejskich stoczni wojennych. Są one specjalnością niemieckiej TKMS. Spółka ta podaje, 
że jest niekwestionowanym liderem na światowym rynku w dziedzinie niejądrowych okrętów podwodnych, a jej produkty stanowią 70\% konwencjonalnej floty okrętów podwodnych NATO (TKMS Thyssen Krupp 2020).

W budowie podwodnych okrętów wyspecjalizowała się także, mniejsza od wyżej wymienionych grup okrętowych, szwedzka stocznia SAAB Kockums. Stocznia ta buduje także lekkie nawodne okręty uderzeniowe oraz korwety. Okręty podwodne budowane są również przez Fincantieri i hiszpańską Navantia ${ }^{6}$.

Szczególną grupą okrętów wojennych są statki o średniej i małej wyporności. Są one budowane najczęściej przez mniejsze samodzielne stocznie wojenne. Te mniejsze okręty wojenne, w zależności od typu, wyposażone są w mniej lub bardziej złożone urządzenia wymagające specjalistycznych technologii wojskowych - zarówno w budowie kadłuba, jak i jego wyposażenia. Część z tych stoczni buduje także małe okręty, jak np. amfibie, statki patrolowe, statki ratownicze itp. Do tej grupy stoczni, obok wyżej wymienionych, należą Damen Schelde Naval Shipbuilding w Holandii, dwie stocznie greckie Eleusis, Hellenic Shipyards w Grecji, dwie stocznie chorwackie - Brodgradiliste Specjalnih Objekata i Kraljevica Brodgradiliste, dwie stocznie polskie - Remontowa Shipbuilding (dawniej Stocznia Północna) i Stocznia Wojenna (dawniej Stocznia im. Marynarki Wojennej), pozostałe stocznie wojenne niemieckie i francuskie niewchodzące w skład wyżej wymienionych grup kapitałowych. Część z tych stoczni buduje także statki handlowe.

Jak opisano powyżej stocznie wojenne krajów UE blisko połowę swej produkcji przeznaczają na eksport. Według danych w latach 2015-2016 eksport stanowił $42 \%$ portfela zamówień europejskich stoczni wojennych (EU Naval Industry 2020, s. 20). Praktycznie wszystkie kraje realizują zamówienia eksportowe. W wielu stoczniach obok podstawowej działalności wykonywane są także remonty okrętów wojennych.

Struktura produkcji stoczni wojennych często wynika z ich struktury własnościowej. Stocznie, w których dominowała wąska specjalizacja produktowa, $\mathrm{z}$ reguły były własnością państwa i najczęściej podlegały ministerstwom obrony narodowej lub ich odpowiednikom. Ten model uległ zmianie i w wielu krajach stocznie te zostały sprywatyzowane. Problem ten opisuje A. Calcara (2018), który pisze, że „prywatyzacja jest szeroka w lotnictwie i elektronice obronnej, natomiast pozostała bardzo ograniczona w sektorze morskim i lądowym. W krajach europejskich występowały istotne różnice $\mathrm{w}$ trajektorii zmian $\mathrm{w}$ strukturze zarządzania przedsiębiorstwami obronnymi. Krajami, które całkowicie sprywatyzowały swój przemysł obronny są Wielka Brytania, Niemcy i Szwecja. Z kolei inne kraje rozpoczęły ten proces znacznie później i w różnym zakresie, dotyczy to np. Francji i Włoch” (Calcara 2018, s. 477).

${ }^{6}$ Na uwagę zasługuje fakt, że łodzie podwodne stanowiły w latach 2003-2012 około 50\% wartości eksportu statków wojennych stoczni świata. 
We wszystkich tych krajach struktura właścicielska nierzadko jest złożona i podlega częstej ewolucji kapitałowej. Dotyczy to także największych europejskich grup kapitałowych. BAE Systems i TKMS to podmioty prywatne o rozproszonej strukturze właścicielskiej. W TKMS większość udziałów posiadają międzynarodowe fundusze inwestycyjne, a 10\% akcji należy do prywatnych udziałowców. Natomiast Naval Group to spółka, która jest własnością kapitału państwowego i kapitału prywatnego ${ }^{7}$, przy czym dominujący jest kapitał państwowy ${ }^{8}$. Odmienną od powyższych była droga biznesowa hiszpańskiej grupy kapitałowej Navantia. Grupa ta powstała z połączenia kilku prywatnych stoczni, której własność po połączeniu przejęło państwo, które posiada $100 \%$ akcji.

Kapitał prywatny dominuje także w innych grupach stoczniowych. Są to grupy zajmujące się głównie budową statków handlowych, ale w których statki wojenne stanowią istotną część działalności. Tak jest w przypadku omawianych wyżej Fincantieri i Damen. W przypadku Fincantieri dominującym właścicielem akcji jest fundusz inwestycyjny CDP Industria S.p.A. (ponad 70\%), który pośrednio kontrolowany jest przez państwo włoskie. Holenderski Damen Schelde Naval Shipbuilding (DSNS), który buduje: fregaty, korwety, amfibie i statki patrolowe funkcjonuje w ramach prywatnej grupy kapitałowej Damen.

W wielu europejskich państwach stocznie budujące średnie okręty wojenne należą do państwa, a ich zarządzaniem zajmują się państwowe spółki kapitałowe. Przykładem jest Stocznia Wojenna w Polsce.

Niezwykle istotnym elementem modelu biznesowego jest podjęcie przez stocznie decyzji, czy w przypadku stoczni wojennych warto podjąć się budowy statków handlowych, a w przypadku stoczni specjalizujących się w budowie statków handlowych - czy wykonywać statki wojenne.

Stocznie, w których dominuje produkcja statków handlowych, często podejmują się budowy okrętów wojennych. Przy czym najczęściej budowane są tutaj okręty o średnim tonażu, takie jak fregaty czy patrolowce oraz małe okręty wojenne floty pomocniczej. Występuje również sytuacja odwrotna, że stocznie o dominującej produkcji wojennej podejmują się budowy statków handlowych.

Często producenci okrętów wojennych podejmują się produkcji urządzeń związanych z działalnością morską, takich jak np. urządzenia do produkcji morskiej energii odnawialnej (np. Naval Group, Navantia).

\footnotetext{
${ }^{7}$ Naval Group jest spółką akcyjną prawa francuskiego, która na dzień 31 grudnia 2019 r. należała w $62,25 \%$ do państwa francuskiego, w $35 \%$ do spółki Thales, a w 1,88\% do pracowników i byłych pracowników (Financial report Naval Group 2020, s. 2).

${ }^{8}$ Bardzo ciekawa jest wypowiedz dhugoletniego dyrektora Naval Group, Herve Guillou, na temat zarządzania tą grupą: „Jesteśmy firmą o statusie prywatnym i niezależnym zarządem, nawet jeśli mamy francuskiego udziałowca rządowego" (Sprenger 2020).
} 
Ta strategia dywersyfikacji prowadzi do korzystnej wzajemnej wymiany między technologiami cywilnymi i wojskowymi (technologie podwójnego zastosowania), zarówno na poziomie głównych wykonawców, jak i na poziomie łańcucha dostaw, prowadząc do opłacalnych projektów i rozwiązań (Study on Industrial and Technological Competences 2016, s. 14).

Stocznie wybierające „czysty” model wojenny bądź wojenno/handlowy lub handlowo/wojenny, lub ,czysty” model handlowy uwzględniają czynniki i argumenty omawiane wyżej (por. pkt 2) dotyczące różnic w budowie statków wojennych i handlowych.

Przyczyn podejmowania się w stoczniach zarówno produkcji statków wojennych i handlowych należy także upatrywać w wahaniach koniunktury (na obu rynkach handlowych i obronnym) oraz dążeniu do pełnego wykorzystania potencjału produkcyjnego.

Z powyższego omówienia wynika, że europejskie stocznie wojenne stosują różne modele biznesowe, które uwarunkowane są posiadanym wyposażeniem stoczniowym, rodzajem własności i wielkości posiadanego kapitału oraz tradycją w budowie okrętów.

\section{Konkurencja i współpraca stoczni wojennych krajów UE}

Podobnie jak w innych sektorach gospodarczych pojedyncze stocznie budujące statki wojenne mogą konkurować lub podejmować współpracę gospodarczą. O ile przy produkcji statków cywilnych najczęściej mamy do czynienia z konkurencją produktową wewnętrzną i zewnętrzną, to w przypadku stoczni wojennych konkurencja produktowa wewnętrzna jest bardzo ograniczona. Z reguły okręty budowane są na potrzeby własnej floty wojennej w ramach krajowych programów produkcji wojennej. Inaczej jest w przypadku produkcji na eksport. Wówczas europejskie stocznie wojenne konkurują o pozyskanie kontraktów z krajów spoza Unii Europejskiej.

Wśród krajów UE, zgodnie z programami rozwoju przemysłu obronnego, podejmowane są działania polegające na wspólnym budowaniu okrętów wojennych $\mathrm{w}$ ramach projektów realizowanych przez stocznie $\mathrm{z}$ różnych krajów. Nie jest to jednak współpraca na zasadzie wykorzystania kooperacji. Realizacja kontraktów na budowę okrętów odbywa się wówczas przez kilka stoczni z różnych krajów. W takiej sytuacji jedna ze stoczni pełni funkcję generalnego wykonawcy, a odpowiedzialność za projektowanie, integrację i budowę okrętów wojennych spoczywa na głównych wykonawcach, którzy w wielu przypadkach działają również jako „organy odpowiedzialne za projekt całego okrętu wojennego”, koordynując szeroki i zróżnicowany łańcuch dostaw (Study on Industrial and Technological Competences 2016, s. 5). 
Największe grupy okrętowe krajów Unii Europejskiej współpracują przy budowie zarówno okrętów podwodnych, jak i nawodnych. Współpraca ta ma najczęściej charakter konsorcjów dla realizacji projektu określonego typu okrętu. Główne typy okrętów lub nazwy programów budowy określonego typu okrętu realizowanych wspólnie przez kilka grup okrętowych przedstawia Tabela 7.

Tabela 7. Współpraca grup kapitałowych w morskim przemyśle wojennym w UE (nazwy projektów)

\begin{tabular}{|c|c|c|c|c|c|c|c|c|c|}
\hline $\begin{array}{c}\text { Grupa } \\
\text { kanitałowa }\end{array}$ & Kraj & \multicolumn{3}{|c|}{ Okręty podwodne } & \multicolumn{4}{|c|}{ Okręty nawodne } & $\begin{array}{c}\text { Join } \\
\text { Venture }\end{array}$ \\
\hline Navantia & ES & & \multirow{2}{*}{ Scorpione } & & \multirow{3}{*}{$\begin{array}{l}\text { Program } \\
\text { EPC + } \\
\text { Grecja }\end{array}$} & & & & \multirow{3}{*}{ NAVIRIS } \\
\hline Naval Gr. & FR & & & & & & & \multirow{2}{*}{ FREMM } & \\
\hline Fincantieri & IT & \multirow{2}{*}{ U212 A } & & & & & & & \\
\hline TKMS & $\mathrm{DE}$ & & & & & \multirow{2}{*}{ F125 } & & & \\
\hline Lurssen & $\mathrm{DE}$ & & & & K130 & & \multirow{3}{*}{$\begin{array}{l}\text { MKS } \\
180\end{array}$} & & Różne \\
\hline Germen NY & $\mathrm{DE}$ & & & & К130 & & & & okręty \\
\hline Damen & NL & & & \multirow{2}{*}{$\begin{array}{l}\text { WALRUS } \\
\text { (WRES) }\end{array}$} & & & & & \\
\hline Kockums & SE & & & & & & & & \\
\hline BAE Systems & GB & & & \multirow{2}{*}{$\begin{array}{l}\text { Vanguard } \\
\text { Class }\end{array}$} & & & & \multirow{2}{*}{$\begin{array}{l}\text { Lotnis- } \\
\text { kowiec QE }\end{array}$} & \\
\hline Babcock & GB & & & & & & & & \\
\hline
\end{tabular}

Źródło: Hanel 2020, Consolidation potential of European naval shipbuilding, Europäische Sicherheit \& Technik, ES\&T Technical Papers, 16.10.2020.

Przedstawione w tabeli programy realizowane są już od szeregu lat, część $\mathrm{z}$ nich jest nowelizowana lub została podpisana w ostatnich latach.

Najnowszym przykładem tego typu współpracy europejskich stoczni wojennych jest rozpoczęcie opracowania wymienionego w Tabeli 7 projektu budowy europejskiej korwety patrolowej EPC (European Patrol Corvette), zatwierdzonego przez Europejską Agencję Obrony (EDA). Projektowi przewodzą Włochy, a w skład jego realizatorów wchodzą Francja, Hiszpania i Grecja - uczestniczące w stałej współpracy strukturalnej (PESCO). Państwa biorące udział w projekcie zamierzają wyprodukować prototyp tej korwety w latach 2026-2027 (EDA2021).

Niezwykle ważną płaszczyzną współpracy wojennych stoczni krajów UE jest ich współdziałanie w zakresie badań i rozwoju. Jest ona realizowana najczęściej w ramach omówionego w punkcie 1 europejskiego planu działań w dziedzinie obronnej (European Defence Action Plan - EDAP) i przy wykorzystaniu Europejskiego Funduszu Obronnego.

Współpraca ta niekiedy wykracza poza ramy związane z innowacjami dotyczącymi produktów wojennych. Tego typu przykładem jest uruchomiony w listopadzie 2019 r. w ramach the European Defense Industrial Development Programme projekt pt. Future naval platforms and related technologies o wartości 15,9 mln euro. Koordynatorem projektu jest Damen Holding B.V. Obok tej firmy jego realizatorami są następujące stocznie: Fincantieri S.P.A., Naval Group S.A. 
(Francja), Navantia S.A. (Hiszpania), Saab Kockums (Szwecja), Thyssenkrupp Marine Systems (Niemcy), Lürssen Defence (Niemcy) oraz kilka innych podmiotów związanych z przemysłem okrętowym, takich jak: Sea Europe oraz podmioty z Danii, Holandii i Hiszpanii. Realizacja projektu rozpoczęła się w 2020 r.

\section{Konsolidacja w morskim przemyśle wojennym krajów europejskich}

W światowym przemyśle okrętowym mamy do czynienia z intensywnymi procesami koncentracji kapitałowej i organizacyjnej. Procesy te występują szczególnie w azjatyckich krajach. W ostatnim okresie doszło do połączenia (lub jest ono w trakcie realizacji) w chińskim przemyśle okrętowym (grupy CSSC i CSIC) oraz koreańskim (Hyundai Heavy Industries HHI i Daewoo DSME). Celem tych połączeń lub fuzji jest przede wszystkim eliminacja wzajemnej konkurencji cenowej w ramach kraju oraz obniżka kosztów budowy statków. Ten sam proces dostrzegany jest w Europie.

Stopień koncentracji produkcji w Europie jest jednak zdecydowanie mniejszy w stosunku do sytuacji w Azji. Dotyczy to zarówno stoczni budujących statki handlowe, jak i tych, które zajmują się budową okrętów wojennych.

Na problem konsolidacji w europejskim przemyśle okrętowym można patrzeć z dwóch perspektyw - perspektywy krajowej i perspektywy międzynarodowej. Renaud Bellais, opisując to, w jaki sposób procesy te przebiegały od końca okresu zimnej wojny, stwierdza, że w tym okresie mieliśmy do czynienia $\mathrm{z}$ wieloma procesami konsolidacji, ale miały one przede wszystkim charakter wewnątrzkrajowy (Bellais 2017). Podobną opinię wyrażają autorzy raportu Mordor Intelligence. Ich zdaniem: „Europejski rynek okrętów wojennych jest skonsolidowany, a dominują na nim takie podmioty, jak Naval Group, Fincantieri, TKMS i BAE Systems. Kluczowi gracze na rynku posiadają kilka stoczni zajmujących się rozwojem okrętów wojennych. Główną strategią generowania przychodów przez największe firmy jest pozyskiwanie kontraktów i zamówień od rządów europejskich i zagranicznych" (Europe Naval Vessels 2020). Odnosząc się do aspektu międzynarodowego, R. Bellais cytuje wypowiedź dyrektora naczelnego European Defence Agency (EDA) - Jorge Domecqa z 2016 r., który stwierdził, że „wraz z końcem zimnej wojny konsolidacja narodowa była powszechnie postrzegana jako warunek wstępny dalszej międzynarodowej konsolidacji, ale po fazie konsolidacji krajowej nie nastąpiła faza ogólnoeuropejska" (Bellais 2017, s. 7). Skutkiem tego europejski przemysł okrętów wojennych pozostaje od 25 lat (czyli końca zimnej wojny) rozdrobniony. Jest to o tyle zaskakujące, że ani konsolidacja transgraniczna, ani programy współpracy nie doprowadziły do restrukturyzacji 
przemysłu statków wojennych Europy. Suwerenny charakter stoczni doprowadził do promowania transformacji przemysłu skoncentrowanej na kraju (Bellais 2017, s. 7). Jorge Domecq przestrzega, że ,ten brak konsolidacji przemysłowej poza granicami kraju zagraża przetrwaniu przemysłu ze względu na bardzo ograniczone i nieregularne obciążenie pracą" (Bellais 2017, s. 7) realizowaną tylko na potrzeby wewnętrzne.

Podobną opinię formułuje H. Guillou, który stwierdza, że przemysł morskich stoczni wojennych w UE obejmujący kilkanaście stoczni jest nadal jednym z niewielu sektorów obronnych w Europie, które nie przeszły żadnej większej konsolidacji w ostatnich dziesięcioleciach. Wobec działań konkurencji azjatyckiej sytuacja ta zagraża utrzymaniu masy krytycznej tego przemysłu w Europie (Guillou 2020a).

A. Rogala-Lewicki, odnosząc się do problemu konsolidacji w europejskim przemyśle okrętowym statków wojennych, pisze, że takie korporacje, jak: Fincantieri, hiszpańska Navantia, holenderski Damen, francuska DCNS (obecnie Naval Group) „pozostają odporne na postępującą konsolidację zarówno w wymiarze krajowym, jak i międzynarodowym" (Rogala-Lewicki 2017, s. 156). Trzeba jednak zauważyć, że opinia ta napisana została przed podjęciem współpracy przez Fincantieri i Naval Group.

Wynika to głównie $\mathrm{z}$ faktu, że próby ograniczania zatrudnienia spotykają się $\mathrm{z}$ protestami społecznymi, a także $\mathrm{z}$ charakteru produkcji i trudnościami integracji wszystkich systemów, w tym np. uzbrojenia, dowodzenia i rozpoznania, a nie samej konstrukcji kadłuba (Rogala-Lewicki 2017, s. 157).

Powszechna opinia o niedostatecznej konsolidacji europejskiego morskiego przemysłu wojennego ${ }^{9}$ oraz radykalne procesy konsolidacji w azjatyckim przemyśle okrętowym doprowadzają do sytuacji, w której - chcąc sprostać wyzwaniom stoczni azjatyckich - w Europie podjęta została próba połączenia działalności dwóch dużych grup kapitałowych Fincantieri i Naval Group.

Fincantieri i Naval Group po dwóch latach rozmów, które rozpoczęły się we wrześniu 2017 r. i zakończyły się w styczniu 2020 r. zdecydowały się utworzyć spółkę joint venture z udziałem 50/50 pod nazwą Naviris (We are Navaris 2021). Spółka ta ma za zadanie, obok realizacji dwustronnych i eksportowych projektów, przygotowanie wspólnych ofert, optymalizację zakupów i realizację wspólnych projektów badawczo-rozwojowych. Zakłada się także wspólne wykorzystanie posiadanych obiektów. Spółka ta stała się jednym z największych podmiotów realizujących budowy okrętów wojennych w Europie. Ma ona pełne poparcie rządów Włoch i Francji.

${ }^{9}$ O konieczności konsolidacji europejskiego przemysłu wojennego piszą także włoscy eksperci ds. obronności CESI w swoim dokumencie, w którym „ostrzegają, że firmy na kontynencie zostaną zmiecione przez zagraniczną konkurencję, jeśli nie uda im się połączyć sił i podbić świata" (Kington i. in. 2018). 
W ostatnim okresie, obok tego pozytywnego przykładu konsolidacji, mamy także do czynienia $\mathrm{z}$ nieudanym procesem łączenia grupy Fincantieri z francuską stocznią Chantiers de l'Atlantique. Oba te przedsiębiorstwa obok okrętów wojennych przede wszystkim specjalizują się w budowie wycieczkowców. Umowa o połączeniu tych podmiotów negocjowana była przez trzy lata. Przedsięwzięcie to spotkało się jednak z wrogością części opinii francuskiej klasy politycznej oraz było negatywnie oceniane przez Komisję Europejską. Zastrzeżenia KE dotyczyły możliwego ograniczenia konkurencji w zakresie budowy statków wycieczkowych. W styczniu 2021 r. uznano, że umowa ta, podpisana przez państwo francuskie i Fincantieri, wygasła z dniem 31 stycznia 2021 r. Nie doszło więc do połączenia obu przedsiębiorstw.

Na dynamikę procesów konsolidacji wpływają także opinie dotyczące wspólnej realizacji konkretnych typów okrętów. Przykładem może być decyzja o zleceniu holenderskiej firmie Damen budowy czterech wielozadaniowych okrętów bojowych klasy 180 . Zdaniem D. Hanela ,istnieją uzasadnione obawy, że przyznanie największego niemieckiego kontraktu morskiego za granicą, jest sprzeczne z niemiecką polityką bezpieczeństwa i interesami technologicznymi, może on bezpowrotnie utracić kompetencje systemowo-techniczne, kluczowe technologie i know-how w RFN, a jednocześnie kompleksowa narodowa konsolidacja niemieckiej budowy okrętów została utrudniona" (Hanel 2021) ${ }^{10}$.

Najdalej idące decyzje ograniczające procesy o współpracy i konsolidacji produkcji okrętów wojennych podjęte zostały w ostatnim czasie przez rząd brytyjski. W ogłoszonej w 2021 r. nowej strategii budowy okrętów wojennych dotyczącej programu rozwoju floty wojennej wymaga się, aby duże okręty wojenne były budowane $\mathrm{w}$ stoczniach krajowych. Podobnie jest $\mathrm{z}$ budową wyposażenia okrętów wojennych, które także powinno być wykonywane w przedsiębiorstwach krajowych. Zlecenia zagraniczne mogą dotyczyć jednostek pomocniczych dla krajowej floty, z tym że każde zlecenie takiego zamówienia będzie oceniane indywidualnie (Chuter 2021).

Przedstawione przykłady i opinie wskazują na to, że procesy konsolidacji w budowie okrętów wojennych w krajach europejskich przebiegają powoli i nie są zaawansowane. Spowodowane jest to ścierającymi się sprzecznymi poglądami na ten temat. Poglądowi o konieczności pogłębienia współpracy w tym zakresie przeciwstawiane są opinie, że prowadzą one do uzależnienia się od partnera dominującego i naruszają interesy suwerenności własnego kraju.

${ }^{10} \mathrm{Z}$ kolei holenderski autor J. Karreman pozytywnie ocenia ten kontrakt, twierdząc, że intensywna współpraca przy realizacji tego projektu może być wstępem do konsolidacji (Karremann 2020). 


\section{Podsumowanie}

Produkcja stoczni wojennych jest elementem polityki obronnej każdego kraju posiadającego tego typu stocznie. W przypadku stoczni wojennych krajów UE zewnętrznym czynnikiem wpływającym na strategie rozwoju tych stoczni jest strategia obronna NATO i polityka obronna Unii Europejskiej. Kraje UE posiadające stocznie wojenne stają przed dylematem dotyczącym tego, w jaki sposób pogodzić własne koncepcje polityki obronnej w zakresie rozwoju krajowych flot wojennych, z założeniami strategicznymi NATO i UE. Polityka obronna UE uwzględnia te dylematy i skupia się przede wszystkim na stworzeniu dostępnych dla krajów europejskich funduszy obronnych.

Czynnikiem wewnętrznym rozwoju sektora stoczni wojennych w poszczególnych krajach europejskich są tradycje rozwoju tych stoczni, posiadany potencjał produkcyjny, wspomniana wyżej strategia obronna oraz możliwości budżetowe.

Z oceny wyników działalności największych europejskich grup kapitałowych produkujących okręty wynika, że dominujące grupy kapitałowe, takie jak BAE Systems i Naval Grup istotnie zwiększyły swoje przychody. Pozostałe grupy mają stabilne wielkości przychodów. Nie potwierdziła się natomiast zawarta w literaturze teza o wyższej rentowności produkcji okrętów wojennych od handlowych. Marże zysku stoczni wojennych są z reguły niskie, niestabilne, a nawet - jak w przypadku hiszpańskiej Navanitia - zdecydowanie ujemne.

Uzyskiwane przychody i osiągane marże zysku są wynikiem przyjętych modeli biznesowych. Na kształt tych modeli istotnie wpływa to, że zamówienia zarówno na statki wojenne, jak i na statki handlowe cechuje duża niestabilność. Powoduje to, że nawet duże stocznie budujące takie okręty, jak lotniskowce, duże fregaty i niszczyciele podejmują się budowy małych okrętów wojennych oraz floty pomocniczej. W okresie zmniejszonego popytu na te statki stocznie starają się także pozyskać zlecenia na inną produkcję, w tym na budowę elementów morskich wież wiatrowych. $\mathrm{Z}$ kolei firmy $\mathrm{z}$ dominującą produkcją statków handlowych podejmują się realizacji kontraktów na okręty wojenne.

W przypadku europejskich stoczni wojennych ważnym elementem strategii rozwoju jest produkcja eksportowa. Stanowi ona często niemal połowę produkcji tych stoczni. O ile w przypadku wewnątrzkrajowym konkurencja jest ograniczona, o tyle w przypadku eksportu europejskie stocznie wojenne konkurują ze sobą.

Stworzone w UE fundusze obronne stały się bodźcem do szerokiej współpracy krajów UE w realizacji wielu wspólnych projektów budowy okrętów wojennych oraz współdziałania w zakresie badań i rozwoju. Podejmowane są także inicjatywy dotyczące konsolidacji przedsiębiorstw produkujących okręty w UE. Procesy te nie są satysfakcjonujące i ustępują swoim zakresem realizowanym 
w krajach azjatyckich. Wynika to z trudności pogodzenia polityki przemysłowej i skierowania jej ku większej suwerenności narodowej, a także zapewnienia bezpieczeństwa narodowego oraz korzyści związanych ze współpracą międzynarodową w ramach UE.

Długofalowa polityka obronna i dążenie do tego, aby stocznie wojenne krajów UE mogły być konkurencyjne na światowym i europejskim rynku okrętowym, wymagają pogłębiających się procesów konsolidacji. Efektywną metodą działania tych stoczni jest także coraz częściej podejmowana wspólna realizacja projektów budowy najnowszej generacji okrętów wojennych.

\section{Bibliografia}

Association of Europe (2020), The Aerospace and Defence Industries Association of Europe, 2020 Facts \& Figures, https://asd-europe.org/sites/default/files/ atoms/files/ASD FactsFigures_2020.pdf (data dostępu: 18.03.2021).

Bellais R. (2017), Against the odds: The evolution of the European naval shipbuilding industry, ,The Economics of Peace and Security Journal”, 12(1). https:// doi.org/10.15355/epsj.12.1.5

Birkler J. et al. (2005), Differences between military and commercial shipbuilding: implications for the United Kingdom's Ministry of Defence, RAND Corporation, RAND National Security Research Division.

Calcara A. (2018), Cooperation and conflict in the European, defence-industrial field: the role of relative gains, „Defence Studies”, 18(4). https://doi.org/10. 1080/14702436.2018.1487766

Chuter A. (2021), New UK naval shipbuilding strategy prizes keeping foreign yards out, Defense News, https://www.defensenews.com/global/europe/2021/03/23/new-uk-naval-shipbuilding-strategy-prizes-keeping-foreign-yards-out/ (data dostępu: 10.05.2021).

EDA (2016), EU naval industry in good shape but more R\&T investment needed, study says. [w:] Global Strategy - What's next for defence?, https://eda.europa.eu/docs/default-source/eda-magazine/edm11singlewebmedres (data dostępu: 11.11.2020).

EDA (2021), Eda to support ,European Patrol Corvette” PESCO project, https:// eda.europa.eu/news-and-events/news/2021/01/04/eda-to-support-european-patrol-corvette-pesco-project (data dostępu: 10.05.2021).

EDA Europe (2016), Study on Industrial and Technological Competences in the Naval Sector, Executive Summary, https://www.eda.europa.eu/docs/default-source/procurement/fns2-final-executive-summary.pdf (data dostępu: 10.03.2021). 
European Commission (2019), Communication From The Commission To The European Parliament, The European Council, The Council, The European Economic And Social Committee And The Committee Of The Regions, European Defence Action Plan.

European Parliament (2021), 9 Europe as a stronger global actor / up to $€ 27$ bn., https:/www.europarl.europa.eu/legislative-train/api/stages/report/current/ theme/europe-as-a-stronger-global-actor/file/review-of-the-european-neighbourhood-policy (data dostępu: 15.02.2021).

Financial report Naval Group (2020), https://www.naval-group.com (data dostępu: 7.05.2021).

Fincantieri, Fincantieri Naval Vessels (2016), https://www.fincantieri.com/globalassets/prodotti-servizi/navi-militari/fincantieri-naval-vessels-brochure.pdf (data dostępu: 7.10.2020).

The Frost \& Sullivan (2017), Global Naval Shipbuilding Market, Forecast to 2026, https://store.frost.com/global-naval-shipbuilding-market-forecastto-2026.html (data dostępu: 15.03.2021).

Guillou H. (2020a), Military naval industry: the urgent need for European consolidation, Fondation Robert Schuman, https://www.robert-schuman.eu/en/ european-interviews/0099-military-naval-industry-the-urgent-need-for-european-consolidation (data dostępu: 13.04.2021).

Guillou H. (2020b), Naval Group: the international market and European industrial consolidation, European Defence Review, Fincantieri, Naval Group, Naviris (data dostępu: 12.10.2020).

Hanel D. (2020), Consolidation potential of European naval shipbuilding, Europäische Sicherheit \& Technik, ES\&T Technical Papers, https://esut.de/ en/2020/10/fachbeitraege/23018/konsolidierungspotenziale-des-europaeischen-marineschiffbaus/ (data dostępu: 13.04.2021).

Imarc (2020), Warship and Naval Vessels Market: Global Industry Trends, Share, Size, Growth, Opportunity and Forecast 2020-2025, https://www.imarcgroup.com/warship-naval-vessels-market (data dostępu: 16.02.2021).

Karremann J. (2020), Konsolidierung der Meeresindustrie in der nördlichen Hälfte Europas. Sicherheit \& Technik, ES\&T Technical Papers, https://esut. de/2020/10/fachbeitraege/22390/konsolidierung-der-meeresindustrie-in-dernoerdlichen-haelfte-europas/ (data dostępu: 13.04.2021).

Kington T. et al. (2018), For Europe, it's naval business as usual, Defence News, https:/www.defensenews.com/global/europe/2018/10/21/for-europe-its-naval-business-as-usual/ (data dostępu: 12.10.2020).

Kulkarni P.R. (2015), Review of Global Naval Shipbuilding Trends and Lessons for Indian Shipbuilding Industry, „Maritime Affairs, National Maritime Foundation", 11(1). https://doi.org/10.1080/09733159.2015.1027076 
Mackenzie C. (2020), „Europeans don't have a choice”: Naval Group boss pushes for shipyard consolidation, Defence News, https:/www.defensenews.com/industry/2020/02/21/europeans-dont-have-a-choice-naval-groupboss-pushes-for-shipyard-consolidation/ (data dostępu: 13.04.2021).

Mordor Intelligence (2020), Europe Naval Vessels Market - Growth, Trends, COVID-19 Impact, and Forecasts (2021-2026), https://www.mordorintelligence.com/industry-reports/europe-naval-vessels-market (data dostępu: 13.05.2021) .

Naval Group (2020), Power at SEA, https://www.naval-group.com/en/group/en-profil/presentation/ (data dostępu: 12.10.2020).

Naval Vessels Market - Growth, Trends, COVID-19 Impact, and Forecasts (20212027), Mordor Intelligence 2020.

Navantia, https://www.navantia.es/en/information-for-contractors/ (data dostępu: 7.10.2021).

Naviris, We are Naviris, https://www.naviris.com/ (data dostępu: 11.04.2021).

Orbis (2020), https://orbis.bvdinfo.com/ (data dostępu: 24.12.2020).

Renaud B. (2017), Against the odds: The evolution of the European naval shipbuilding industry, „The Economics of Peace and Security Journal, EPS Publishing", 12(1). https://doi.org/10.15355/epsj.12.1.5

Rogala-Lewicki A. (2017), Integracja europejskiego przemystu obronnego, „Przegląd Geopolityczny”, 19.

Smit W.A. et al. (2001), Naval Shipbuilding in Europe [w:] Elsner W. (red.), International Restructuring and Conversion of the Arms Industries and the Military Sector. Industrial, Regional and Sociocultural Aspects. Proceedings of the International Conversion Conference Bremen.

Sprenger S. (2020), You need two to tango: Naval Group CEO Hervé Guillou on business in Europe and Down Under, Defence News, https://news.yahoo. com/two-tango-naval-group-ceo110430671.html?guccounter (data dostępu: 12.10.2020).

TKMS - Thyssen Krupp Marine System, https://www.thyssenkrupp-marinesystems.com/en/portfolio.html (data dostępu: 5.05.2021).

Wilczyński P.L. (2015), Rozmieszczenie europejskiego przemystu stoczniowego w branży zbrojeniowej, „Prace Komisji Geografii Przemysłu Polskiego Towarzystwa Geograficznego", 29(1): 138-161. 


\section{Summary}

\section{Development strategies and business models of the Largest Naval Shipbuilding Groups in the European Union}

The aim of the article is to analyze development strategies and adopted business models in the largest capital groups dealing with the construction and equipment of naval ships in the European Union countries. Warship construction and equipment production have been found to constitute the largest part of the European shipbuilding industry. The subject of the assessment included British BAE Systems, French Naval Group, German TKMS in Germany, Spanish Navantia, Swedish SAAB Kockums, Italian Fincantieri, and Dutch Damen.

The analysis shows that one of the basic factors shaping the development strategies of European naval yards is defense policy of the EU and NATO. The EU policy focuses on providing funds for production of new vessels and R\&D funds that are available to EU members. These factors and the adopted business models were reflected in the volume of revenues of the largest capital groups and in profit margins. The obtained data shows that the financial condition of these companies is not stable. The business models of the analyzed enterprises differ significantly in terms of the types of ships built, as well as the ownership and capital structure. A common feature of these groups' activities is cooperation in the implementation of shipbuilding projects within the EU and striving to consolidate within large capital groups. However, the dynamics of the consolidation processes is relatively low and there is a risk that the competitiveness of naval yards may be insufficient in the face of aggressive actions undertaken by Asian naval shipyards.

Keywords: naval shipbuilding, warship production, naval vessels, military ship construction, consolidation, cooperation 